\title{
Algal Community Membership of Estuarine Mudflats from the Savannah River, United States
}

\author{
Kalina M. Manoylov ${ }^{1, *, \dagger}$, Yenkang Ellen France ${ }^{1, \dagger}$, Abeselom Geletu ${ }^{1}$ and \\ Joseph N. Dominy Jr. ${ }^{1,2}$ \\ 1 Department of Biological and Environmental Sciences, Georgia College and State University, Milledgeville, \\ GA 31061, USA; ellen.france@gcsu.edu (Y.E.F.); geletu.abeselom@gmail.com (A.G.); \\ Joe.Dominy@imerys.com (J.N.D.J.) \\ 2 Imerys Ceramics, Langley, SC 29834, USA \\ * Correspondence: kalina.manoylov@gcsu.edu; Tel.: +1-478-445-2439; Fax: +1-478-445-5290 \\ + Those authors contributed equally to this work.
}

Academic Editor: Angelika Brandt

Received: 16 October 2015; Accepted: 29 January 2016; Published: 22 February 2016

\begin{abstract}
Algae represent a large and diverse group of photosynthetic organisms inhabiting all aquatic habitats. Although the traditional assessment of algal diversity relies mainly on microscopy-based morphological identification, certain limitations exist. In this study, we present a combined molecular and morphological assessment of algal diversity in mudflats from the Savannah River Estuary, Georgia. High diversity of diatoms was documented, and less than $20 \%$ of the algal community was physiologically active at the time of collection. From the total genomic DNA extracted from the field samples and lab isolates, $18 \mathrm{~S}$ rDNA sequences were PCR amplified, cloned, sequenced, identified, and then compared to the taxa identified via microscopy. Only a few of the DNA sequences matched documented taxa, and the abundance of particular algal species was limited to morphological analysis. Surprisingly, upon examination of the remaining lysis buffer from the mechanical lysis step of algal cells, diatom species were left intact even in the presence of a detergent indicating that the diatom species resistant to lysis could be easily underrepresented. Generation of additional algal sequences data, tied to accurate taxonomic identification, is essential to current environmental sequencing projects and potentially would allow faster acquisition of algal community structure within these unique environments.
\end{abstract}

Keywords: Savannah River; diatoms; mudflats; species identification

\section{Introduction}

Estuaries can be defined as partially enclosed bodies of coastal water with a free connection to the open sea, within which seawater is diluted by a freshwater system [1]. These areas contain varying amounts of salinity and nutrients dependent upon tidal changes and upstream runoff. Within the coastal waters of the U.S. alone, nutrient eutrophication is often the primary cause of numerous diverse coastal problems. Disturbances include red tides, fish kills, marine mammal deaths, shellfish poisoning, hypoxia, and anoxia [2,3]. Often times, these events are preceded by changes in algal species composition. Thus, the importance for studying primary producers from these dynamic ecosystems may provide answers for prevention of large-scale disturbance within those ecologically important habitats.

Intertidal zones are often referred to as littoral zones, and are characterized as the foreshore portion that is exposed to the atmosphere during low tide events and covered at high tide. Algal communities inhabiting those areas consist of a mixed flora containing freshwater, brackish, and 
marine species. Mud samples found within littoral zones contain both epipelic and epipsammic diatoms [4]. These primary producers serve as a food source for many groups of surface sediments feeders [5] and also act as agents of biogenic stabilization through the fast synthesis of a mucilaginous matrix during low flow [6,7]. Mud samples within estuaries reflect algal distribution patterns related to gradients of temperature, desiccation, salinity, and organic pollution [8]. It is likely that the distribution of aquatic species along so many variables is not disjunctive, but rather represents a continuum within the habitat. Therefore, species composition of primary producers within mud samples is a result of complex interactions varying between environmental factors and inter- and intra-specific competitive interactions [9].

Algae are a heterogeneous, photoautotrophic group of organisms ubiquitously found in aquatic habitats, such as oceans, seas, freshwater lakes, ponds, and streams. As primary producers, algae conduct up to $40 \%$ of the global photosynthesis [10], contributing to a significant portion of atmospheric oxygen [11]. In addition to their ecological importance as primary producers and chemical modulators of aquatic ecosystems, the use and applications of various algal species for environmental studies have increased in recent years. Prokaryotic presence in marine sediments has been addressed [12], but very few studies look at the eukaryotic primary producer in sediment [13]. Diatoms, which exist in almost all aquatic environments, play important roles as useful bioindicators for monitoring water quality $[14,15]$. Despite displaying an incredible biodiversity and ecological importance, the diversity of algae has not been fully explored [16]. Among the estimated 10 million algal species present in nature, only 100,000 of them have been identified, and there is a great deal of work that remains to be done for a more comprehensive understanding of their diversity. Although the microscopy-based study of algal diversity has been the conventional and primary method of taxonomic studies, this method has various limitations [17]. The methodology is time-consuming, and identification requires expertise in taxonomy; more importantly, the resolution allowed by light microscopy is limited in differentiating species of extremely small size, resulting in underestimation of the actual species diversity [18]. In addition, the microscopic approach suffers from setbacks related to the scarcity of morphologically important markers in some species, adding to the problem of underrepresentation. Microscopic identification of live and dead diatoms at the time of collection allows for the examination of total species available in a community and physiologically active species. However, even when documented as live, cultivating some of the algal species in cultures is known to be difficult [19]. Even if successful and widely used, the culture-dependent approach can result in bias towards species that thrive well in culture conditions, and leave unaccounted those that are resistant to cultivation by standard culture methods [20]. Additionally, morphological changes in response to environmental conditions can potentially mislead the microscopic identification. Thus, the microscopy and culture-dependent approach alone may not reflect the true diversity in the environment [21], which calls for evaluation of current identification and processing approaches in algal assessment as a complement to the conventional microscopic approach. The ultimate goal of this research is to better understand the high algal diversity in estuarine environments.

One alternative approach for taxonomic studies is molecular systematics based on nucleotide sequence comparisons. For nucleotide sequence-based taxonomic studies, unlike the cultivation-dependent approach, a live cell is not required, only a DNA sequence. Cloning and sequencing highly conserved genes, such as the Small Subunit (SSU) ribosomal DNA (rDNA), obtained from environmental samples can be used to objectively classify microbes and their diversity in the ecosystem [22]. This goal is accomplished by comparing the sequences with reference sequences of known species. Molecular approaches have been successful thus far, despite the limited availability of known algal-specific nucleotide sequences in databases. Studies that employed molecular tools for taxonomic purposes detected a number of new groups that could be assigned to existing phyla [23]. Furthermore, the work by Viprey et al. [24] showed that great diversity existed within the already established taxa. 
In this study, we present a combined approach, in which molecular protocols were incorporated in assessing algal diversity from environmental samples. The objective of this research was to develop a methodology for better taxonomic identification of algal communities with precise analyses of the percentage of diatoms within the natural algal communities from the southeastern United States. The mud samples taken from the Savannah River Estuary, Georgia, which is known to be rich in algal biodiversity [16], were split into two aliquots. The mud samples were subsequently used for total genomic DNA extraction and for a morphological assessment in parallel; then, the results from the molecular and morphological identifications were compared. Diatoms from the same field samples were also cultured in the laboratory to provide positive control DNA sequences in the molecular community assessment. As anthropogenic changes continue to occur, such as the deepening and widening of the Savannah River Port, algal biodiversity will be altered in all related habitats, including mudflats, and we will be able to evaluate the direction and extent of these changes as we have established the baseline diversity with the current study.

\section{Experimental Section}

\subsection{Study Sites and Sampling}

Five mud samples were taken from the Savannah River Estuary in December 2011 (Savannah River United States Geological Survey (USGS) site 2198920, Lat 32 09'57", Long 81 $09^{\prime} 14^{\prime \prime}$ ). The sampling methods followed the standard protocols of the American Public Health Association [25]. At the time of collection the following physical and chemical field data was collected: Dissolved oxygen $7.8 \mathrm{mg} / \mathrm{L}$, Total nitrogen $0.57 \mathrm{mg} / \mathrm{L}$, Total phosphorus $0.22 \mathrm{mg} / \mathrm{L}, \mathrm{pH} 7.7$, conductivity $14,500 \mu \mathrm{S} / \mathrm{cm}$, turbidity $50 \mathrm{NTU}$, and temperature air $8.2 /$ water $13.7^{\circ} \mathrm{C}$. Two of the samples were used for initial whole algal community analyses, performed immediately upon returning to the laboratory. In addition, within $24 \mathrm{~h}$ of collection, observed viable algae were isolated and placed in medium for growth. The mudflats had a combination of freshwater, marine and brackish taxa [26]; therefore, there were 3 possible culturing conditions for each isolate, based on algal preference. Freshwater algae were grown in Bolds medium. Marine algae were grown in filtered water from the location and salt-water medium (Guillard's F/2 Marine Water Enrichment Solution, Sigma Aldrich G0154, St. Louis, MO, USA). A 1:1 ratio of Bolds media (Sigma Aldrich, B5282) and salt-water medium was used to grow brackish taxa. Subsequently, the algal cultures from the Savannah River were started in liquid media and agar plates. That was required to provide suitable artificial conditions for planktonic or epipelic/epipsammic habitat preference of the live algal individuals. Isolated algal species were designated either freshwater (if appeared in the NAWQA list for the last 20 years in both rivers and lakes) or marine unless the original description designated it as being brackish. Specific data from Underwood [9] was used to confirm our classification for common species. Live field samples and cultures in different stages of development were maintained in a controlled environmental chamber (Percival Scientific, Inc. Model I-366LL, Perry, IA 50220, USA). The cultures in the incubator were kept at $18^{\circ} \mathrm{C}$ and under a $14 \mathrm{~h}$ of light and $10 \mathrm{~h}$ of dark cycle. Full light in the chamber was $96-100 \mu \mathrm{mol} \cdot \mathrm{m}^{-2} \cdot \mu \mathrm{mol} \cdot \mathrm{s}^{-1}$. Humidity was $90 \% \pm 5 \%$ and was controlled with a microprocessor.

\subsection{Morphological Assessment}

The taxonomy of the algal community was enumerated in three field mud samples, following the Standard Methods [25], by assessing the whole community analyses in a Palmer Maloney counting chamber [27] (colonial forms can be observed as the depth of the chamber is $0.4 \mathrm{~mm}$ ) or on flat slides at $400 \times$ (algae flattened in a single layer, higher resolution achieved). A minimum of 300 live natural algal units (single cells, filaments or colonies) and cell numbers within units (including diatoms) were identified and enumerated to the lowest taxonomic level. Then, the remainder of the subsample in the Palmer Maloney chamber and 2-5 additional subsamples were scanned to observe new algal species to determine the species richness until no new live taxa were observed on 2 consecutive transects. 
In the total community assessment, all algae analyzed were assumed to be physiologically active due to visible, healthy looking chloroplasts.

The taxonomy of the diatom community was specifically assessed on samples treated with a strong acid to increase species level identification accuracy. For the samples in which whole community DNA was isolated and to increase certainty in the diatom species identification, $10 \mathrm{~mL}$ of the remnant preserved samples was digested with nitric acid to remove all organic matter. A permanent diatom slide was prepared with the acid-cleaned material mounted in Naphrax resin for increased clarity (RI 1.74, The Biology Shop, Hazelbrook, New South Wales, Australia). For the diatom counts, 600 diatom valves were identified and counted to determine the species' relative abundances. Then, the whole surface of the cover slip was scanned, and all diatom species were recorded. The identification was based on the current literature [28-33]. Permanent slides were archived and deposited as part of the diatom slide collection of the Georgia College and State University (GCSU) Natural History Museum.

\subsection{Culturing of Isolates from Environmental Samples}

Single viable cells from the composite field samples were isolated one at a time. Viable algal cells were taken with a glass tip and placed in a vial with a liquid medium or in a petri dish with agar medium. In the process we potentially took more than one species as algal cell size ranged from 12 to $140 \mu \mathrm{m}$. Algal isolates grew under artificial conditions as described above with the goal to increase number of cells within populations and increase yield in DNA isolation. Growth was monitored every third day. After observing increase in abundance, cultures grown in liquid or in agar medium were combined for DNA extractions. Thus, we created subsets of the natural community with known membership and expected higher matching with morphology.

\subsection{Genomic DNA Isolation}

Environmental DNA isolation was attempted for the total community from the mud sample-sediment, composite liquid cultures, and composite agar culture. Total genomic DNA was extracted from the algal culture and sediment samples using the MO BIO Power Soil DNA Isolation kit (MoBio PowerSoil DNA kit; Mo Bio Laboratories, Carlsbad, CA, USA), according to the manufacturer's instruction. Briefly, $500 \mu \mathrm{L}$ of samples was added to the Power Bead and lysis buffer-containing tubes provided in the kit, followed by the addition of Solutions $\mathrm{C} 1$ through $\mathrm{C} 5$. The DNA was eluted off of the column using the $\mathrm{C} 6$ elution buffer. The DNA concentration and quality was then determined using a Nanodrop ND-100 Spectrophotometer (Wilmington, DE, USA). The extracted genomic DNA samples were stored at $-20^{\circ} \mathrm{C}$ prior to the continuation of the cloning experiments.

\subsection{PCR Amplification Using 185 rDNA Primers}

The eukaryotic $18 \mathrm{~S}$ rDNA universal primers published in previous studies were used to amplify $18 \mathrm{~S}$ rDNA genes, using the total genomic DNA as template [34]. The sequences of the forward and reverse primers used were $1 \mathrm{~F}$ (5'-CTG GTT GAT CCT GCC AG-3') and 1520R (5'-CYG CAG GTT CAC CTA C- $3^{\prime}$ ), respectively. PCR amplification was performed using a Phusion ${ }^{\circledR}$ High-Fidelity PCR Kit (New England Biolabs Inc., Bio Laboratories, Carlsbad, CA, USA), according to the manufacturer's instruction. The $18 \mathrm{~S}$ rDNA was amplified under the following conditions: The PCR reaction mixture contained $0.5 \mu \mathrm{M}$ of each of the forward (F) and reverse (R) primers, $10 \mu \mathrm{L}$ of GC buffer at a final concentration of $1 \times, 200 \mu \mathrm{M}$ of dTNPs, $5-10 \mu \mathrm{L}$ of template DNA for each sample, and 1.0 unit of DNA polymerase, and it was brought to a final reaction volume of $50 \mu \mathrm{L}$ with $\mathrm{ddH}_{2} \mathrm{O}$. The touch down PCR reaction parameters were set as follows: after the initial denaturation at $98^{\circ} \mathrm{C}$ for $30 \mathrm{~s}$, the first 10 cycles were performed by denaturation at $98^{\circ} \mathrm{C}$ for $10 \mathrm{~s}$, and the annealing temperature started at $62.9^{\circ} \mathrm{C}$ and was lowered by $1{ }^{\circ} \mathrm{C}$ for each cycle until it reached $53.9^{\circ} \mathrm{C}$, followed by an extension at $72{ }^{\circ} \mathrm{C}$ for $30 \mathrm{~s}$. The remaining 25 cycles were run by denaturation at $98^{\circ} \mathrm{C}$ for $10 \mathrm{~s}$, annealing at $53.9^{\circ} \mathrm{C}$, and a $30 \mathrm{~s}$ extension at $72{ }^{\circ} \mathrm{C}$, followed by the final extension of $5 \mathrm{~min}$ at $72{ }^{\circ} \mathrm{C}$. 
To isolate the PCR product of the predicted size from the background smear, the PCR product was first resolved on a 1\% agarose gel, followed by excising the band size of approximately $2 \mathrm{~KB}$, then extracting it from the agarose using QIAquick Gel Extraction Kit (Qiagen, Valencia, CA, USA), according to the manufacturer's instruction. DNA was then eluted from the column by the addition of $32 \mu \mathrm{L}$ of EB buffer. The PCR products obtained from the genomic DNA extracts of sediment and cultured samples displayed a size of approximately $1700 \mathrm{bp}$. DNA purity was checked at every stage, starting from the gel extraction of PCR fragments to sequencing. The DNA purity, based on the $A_{260} / A_{280}$ ratio, was within the range of 1.6-1.8.

\section{6. $18 \mathrm{~S}$ rDNA Cloning and Plasmid DNA Isolation}

The PCR-amplified 18S rDNA products were subsequently cloned into the $\mathrm{PCR}^{\circledR}{ }^{\circledR} 4 \mathrm{Blunt}$-Topo ${ }^{\circledR}$ vector of the Zero Blunt ${ }^{\circledR}$ TOPO $^{\circledR}$ PCR Cloning Kit (Invitrogen, Carlsbad, CA, USA) following the manufacturer's instruction. Then, the cloning reaction mixture was transformed into One Shot ${ }^{\circledR}$ Chemically Competent E. coli cells provided with the kit (Invitrogen), following the manufacturer's protocol. Positive transformants were picked and cultured overnight in LB liquid medium containing kanamycin $(50 \mu \mathrm{g} / \mathrm{mL})$. The isolation of plasmid DNA was conducted using a QIAprep ${ }^{\circledR}$ Spin Miniprep Kit (Qiagen). Plasmids were checked for inserts by restriction analysis with EcoRI (New England Bio-Labs, Ipswich, MA, USA) digestion overnight at $37^{\circ} \mathrm{C}$, followed by the separation of DNA fragments on $1 \%$ agarose gels containing ethidium bromide.

\subsection{Restriction Fragment Length Polymorphism (RFLP) Analyses of $18 \mathrm{~S}$ rDNA}

Plasmids positive for PCR products were further analyzed and compared by Restriction Fragment Polymorphism (RFLP) analysis to reduce the redundancy of clones for distinct identity for sequencing. Briefly, $4 \mu \mathrm{L}$ of isolated plasmid DNA from each bacterial colony was digested with the restriction enzymes, AluI and MspI (New England BioLabs) overnight at $37^{\circ} \mathrm{C}$. The restricted DNA fragments were resolved on $2 \%(w / v)$ agarose gels in $0.5 \times$ TBE. The restriction profile was captured using a PhotoDoc-It Imaging System (Ultra-Violet Products Ltd., Upland, CA, USA) and manually screened to avoid redundancy. Only distinct $18 \mathrm{~S}$ rDNA inserts were selected for sequencing. The effectiveness of $A l u \mathrm{I}$ and $\mathrm{Msp \textrm {I }}$ restriction digests in discriminating $18 \mathrm{~S}$ rDNA sequences from very closely relates species was tested by comparing the hypothetical RFLP patterns using the same enzymes via the Geneious version R7 (http:/ / www.geneious.com [35]).

\subsection{DNA Sequencing and Analyses}

Non-redundant clones were completely sequenced using the T3 primer at Sequetech (Mountain View, CA, USA), and the sequences were analyzed using Orientation Checker [36] to identify and correct their orientation. The resulting processed sequences were subsequently tested by Pintail [37] to detect low quality sequences and chimeric gene artifacts.

The sequences obtained from this study were used as queries to identify the nearest identifiable matches from existing eukaryotic sequences in the GenBank and EMBL databases using the BLAST search engine. The top five closest eukaryotic sequences retrieved from the EMBL and NCBI sequence databases for each distinct sequence were subsequently aligned with the corresponding query sequences using ClustalW and ClustalX version 2 [38], which is the Multiple Sequence Alignment tool of the EMBL [39]. The remainder of the $18 \mathrm{~S}$ rDNA clone sequences were searched by BLAST for sequence similarities and aligned with reference sequences of the highest similarity scores obtained from GenBank and SILVA [40] using ClustalW [41]. Finally, the sequence with the highest similarity, as well as the closest phylogenetic relationship to the query sequence determined by the alignment tool, was selected as the closest match. 


\section{Results and Discussion}

\subsection{Morphological Analyses}

A total of 198 algal taxa were documented from 5 samples collected in December 2011. From the whole algal community enumeration, less than $20 \%$ of the observed algae were alive at the time of collection. Ninety percent of the live algae were diatoms while cyanobacteria, and green algae were documented in small quantities. Thirty-five taxa were isolated in different media dependent on classification and distribution data [26]. Growth in the artificial environments was documented for 18 isolates.

In the diatom community analyses, there were 188 diatoms, and species richness varied from 31 to 84 (average $72 \pm 12 \mathrm{SE}$ ) in the 600 valve enumeration. Marine benthic diatoms dominated the community and were represented by Achnanthes brevipes Agardh, Tryblionella littoralis (Grunow) Mann, and Gyrosigma litorale (W. Smith) Cleve. Abundant marine planktonic diatoms included Campylosira cymbelliformis (Schmidt) Grunow in Van Heurck, Pseudonitzschia cf. australis Frenguelli, Cylindrotheca gracilis (Brébisson) Grunow, Cymatosira belgica Grunow, and Thalassionema nitzschioides (Grunow) Mereschkowsky. The Savannah River Estuary had high nutrient contents as measured in the field and based on the presence of the following taxa: Navicula rostellata Kützing, Sellaphora pupula (Kützing) Mereschkowsky, and Nitzschia brevissima Grunow ex Van Heurck [17]. Riverine freshwater diatoms, such as Bacillaria paradoxa Gmelin, Pleurosira laevis (Ehrenberg) Compère, Cyclotella atomus Hustedt, Melosira varians Agardh, and Discostella stelligera (Hustedt) Houk and Klee, were potentially deposited in the mud with changes in the water level due to diurnal tides from the Atlantic Ocean [26]. Brackish diatoms, such as Biremis circumtexta (Meister ex Hustedt) Lange-Bertalot and Witkowski and Skeletonema potamos (Weber) Hasle, were common and documented alive.

\subsection{Molecular Analyses}

The PCR products obtained from the genomic DNA extracts of sediment and cultured samples displayed a fragment of approximately $1700 \mathrm{bp}$ in length (Figure 1). The plasmids isolated from the bacterial transformants were checked via restriction digest to make sure that the plasmid contains the insert of the correct size corresponding to the PCR product, and the plasmids that did not have the right insert were removed (data not shown).

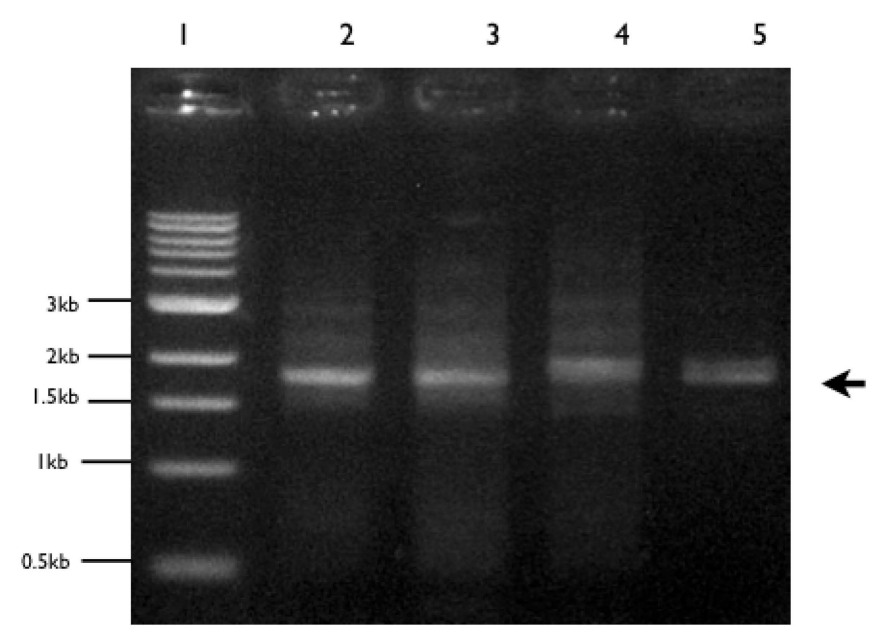

Figure 1. PCR products amplified from genomic DNA from field mudflat sample and laboratory developed cultures from Savannah River. Lane 1: 1 KB DNA Ladder; Lane 2: DNA template from field mudflat sample; Lane 3: DNA template from freshwater habitat (used for comparison); Lane 4: DNA template from agar culture; Lane 5: DNA template from liquid culture. Arrow indicates the genomic PCR products. 
A total of $16018 \mathrm{~S}$ rDNA clones that we purified were subjected to RFLP analysis (Figure 2) to remove redundant clones. To test whether the RFLP analyses of cloned sequences would allow the fine discrimination between closely related species, we performed a hypothetical RFLP analysis using the $18 \mathrm{~S}$ rDNA sequences of several closely related species within the same genera from the Genbank using the Geneious R7 [35]. The result validated the use of AluI and MspI combination in generating restriction patterns different enough to distinguish the closely related species within the same genera (Data not shown). The final 59 non-redundant clones selected were sequenced via the Sanger sequencing method. The chimera detection software, Pintail, detected three chimeric and 17 low quality sequences of the 59 clone sequences, and these sequences were excluded from further analyses. Forty-one matches in GenBank were analyzed. The taxonomic groups identified based on the DNA source were variable. In the field mud sample from the Savannah River, there were no sequences that related to taxa documented morphologically.
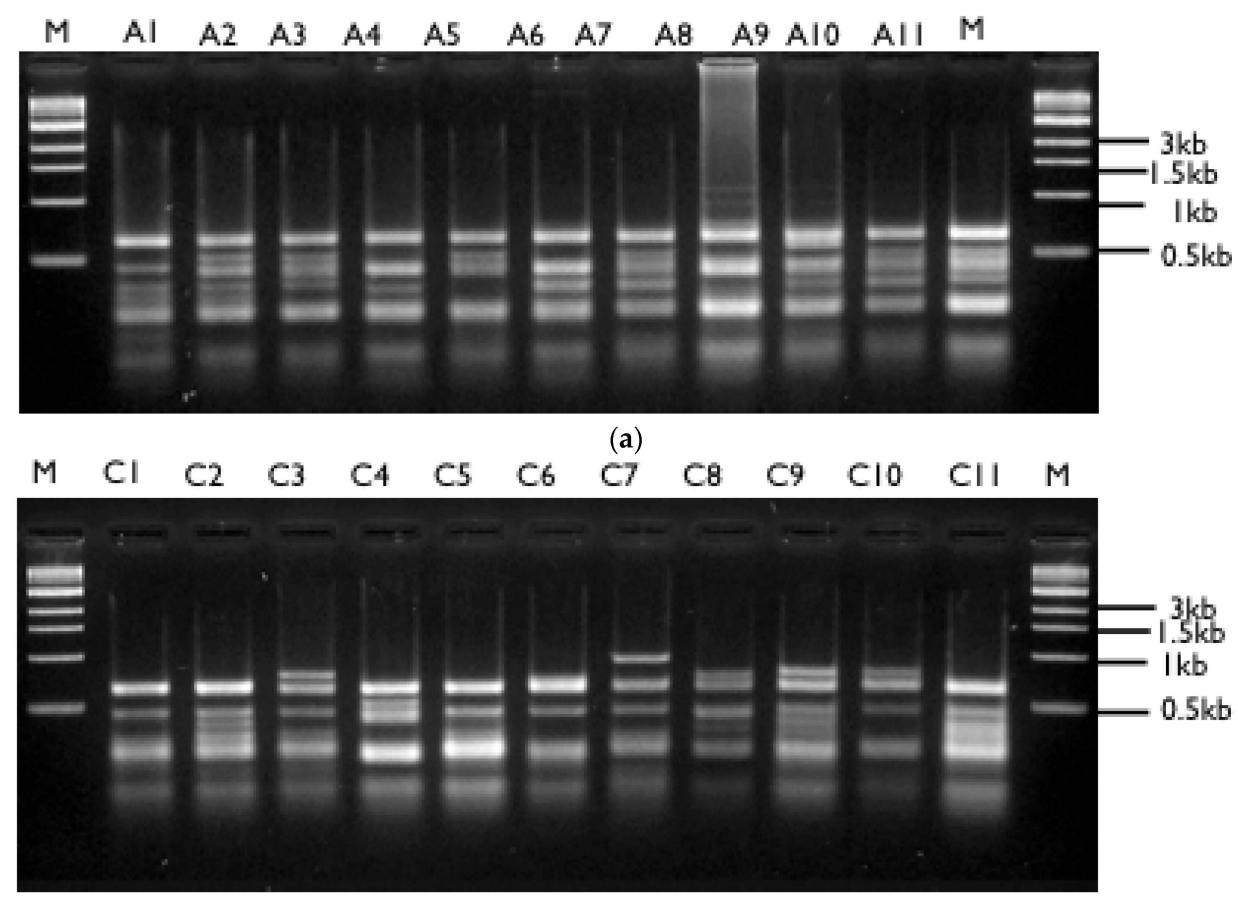

(b)

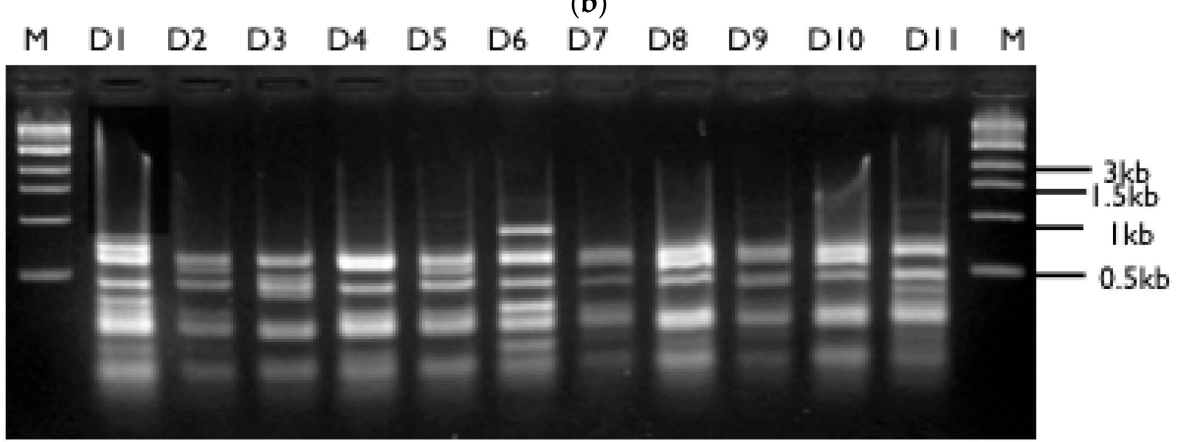

(c)

Figure 2. RFLP profiles of $18 \mathrm{~S}$ rDNA obtained from unique clones using AluI restriction digest. (a) Savannah River mudflat sample; (b) Agar medium grown cultured material from Savannah River mudflat; (c) Cultured material in liquid media from Savannah River mudflat.

Finally, on the agar culture plates, there were matches of taxonomic representatives from unknown eukaryotes, photosynthetic Stramenopiles (diatoms and Chrysophyta), Cryptophyta, Amoebozoa, and Metazoa (Table 1). 
Table 1. List of algae identified via $18 \mathrm{~S}$ rDNA sequence based BLAST search from the Genbank Clone sequence from A: Savannah River; B: Subculture samples of Savannah River on agar plates; and C: Subculture from Savannah River in liquid media.

\begin{tabular}{cccccc}
\hline Taxon & $\begin{array}{c}\text { Savannah River } \\
\text { DNA Source }\end{array}$ & Similarity & Group & $\begin{array}{c}\text { Level } \\
\text { Identification }\end{array}$ & Genbank\# \\
\hline Odontella sinensis & A & 89 & Bacillariophyta & Species & Y10570 \\
Biddulphia sp. CCMP & B & 95 & Bacillariophyta & Genus & EF585585 \\
$\begin{array}{c}\text { 14718Sr RNA gene } \\
\text { Surirella sp. }\end{array}$ & B & 97 & Bacillariophyta & Genus & FR865515 \\
$\begin{array}{c}\text { Pleurosira cf. laevis } \\
\text { clone p203 }\end{array}$ & B & 99 & Bacillariophyta & Species & AJ535188 \\
$\begin{array}{c}\text { Cerataulus smithii } \\
\text { Paraphysomonas }\end{array} \quad$ B & B & 94 & Bacillariophyta & Species & HQ912666 \\
$\begin{array}{c}\text { Cymbella aspera } \\
\text { Hydrosera sp. }\end{array} \quad$ B & B & 99 & Chrysophyta & Species & Z28335 \\
$\begin{array}{c}\text { Goniomonas truncata } \\
\text { clone }\end{array}$ & C & 98 & Bacillariophyta & Species & AM502016 \\
\hline
\end{tabular}

Algal taxa identified via $18 \mathrm{~S}$ rDNA sequence analyses corresponded to very few of the taxa identified morphologically. Only a few clone sequences from our $18 \mathrm{~S}$ rDNA clone libraries matched the sequences of diatoms to genus or species level, namely Cymbella aspera (Ehrenberg) Cleve, Biddulphia sp., and Pleurosira laevis (Figure 3). The preparation and processing of algal samples for genomic analysis requires phycological background because the biochemical compositions of the cell wall vary greatly from species to species, and the environments in which various species thrive are immensely different from one another. These complexities also lead to a challenge in developing appropriate culturing conditions for different species under laboratory settings.
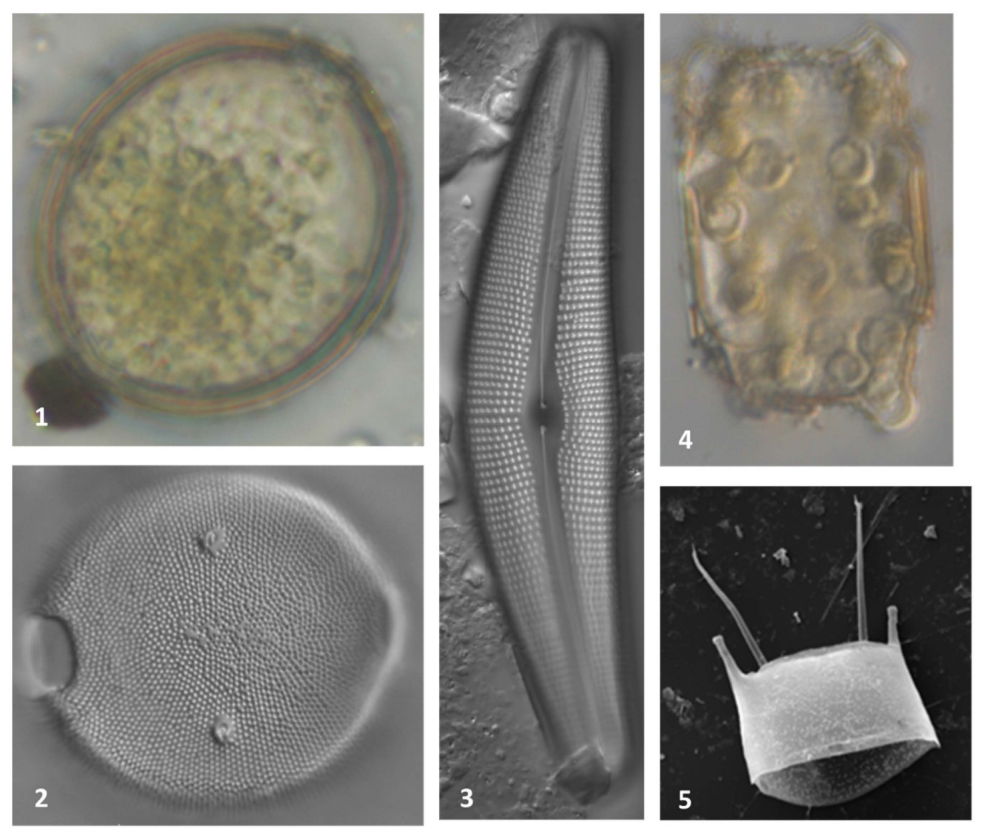

Figure 3. Diatom taxa corresponding to $95 \%$ or greater similarities based on molecular identification: $(\mathbf{1}, \mathbf{2})$ Pleurosira laevis; (3) Cymbella aspera; (4) Odontella (Biddulphia) sp. live; (5) Odontella (Biddulphia) sp. girdle band; (1-4) light microscope images; (1,4), live images; and (5) SEM image. Scale bar $10 \mu \mathrm{m}$. 
From both the field and algal isolates samples, we identified a high number of $18 \mathrm{~S}$ rDNA clone sequences of other heterotrophs and unknown sequences. Metazoa comprised $97 \%$ of the total $18 \mathrm{~S}$ rDNA of field sediment samples collected from the Savannah River, whereas the unknown ribosomal sequences constituted 3\%. Of the total $18 \mathrm{~S}$ rDNA obtained from the subset of algal isolates of the Savannah River samples on solid agar plates, the highest percentages were of unclassified sequences (52\%), followed by Amoebozoa (29\%), Stramenopiles (14\%) and Metazoa (5\%). Algal isolates grown in liquid medium showed the highest percentage of diatoms ( $88 \%)$, followed by Cercozoans $(6 \%)$ and Kinetoplastids (6\%). Similarities among our sequences and the previously published reference sequences ranged from $89 \%$ to $99 \%$.

Our results showed that $18 \mathrm{~S}$ rDNA could be successfully amplified from genomic DNA extracts of environmental and algal isolates from sediment samples by following a modified PCR protocol. Additionally, these PCR products were successfully ligated into plasmid vectors to obtain distinct bacterial clones containing only one type of $18 \mathrm{~S}$ rDNA. The finding that algae constituted a relatively low percentage of the $18 \mathrm{~S}$ rDNA clone sequences in our libraries may stem from several factors. First, the number of clones we generated for sequencing was rather low as we intended to test the existing method to troubleshoot and refine the methodology. However, this low identity may also indicate the possibility that certain algae may be resistant to efficient lysis during genomic DNA extraction prior to cloning. Indeed, we observed samples that were subjected to mechanical lysis via "bead beating" during the cell lysis procedure of the protocol, and we found that many of the diatoms were still alive with intact frustules and chloroplasts (Figure 4). This observation suggested that diatoms grown under artificial conditions might have altered cell physiology, allowing them to become resistant to mechanical and detergent-based cell lysis. This resistance could potentially interfere with the accurate quantification of species richness via molecular detection as DNA of the species that are resistant to lysis would likely be underrepresented in a total genomic DNA preparation. A similar study [41] showed that there was a large disparity between the cell count and identified 18S rDNA sequences, supporting the possibility of inefficiency in the specific DNA extraction protocol employed. Another study published by Nguyen, et al. [42], which compared several DNA extraction methods, concluded that there were differences in the extraction efficiencies of DNA from freshwater diatoms using the currently available protocols and different reagents. Thus, our finding strongly suggested that DNA extraction should be further optimized to efficiently extract genomic DNA from algae to avoid bias in future experiments. The other possibility for the low percentage of algal $18 \mathrm{~S}$ rDNA clone sequences is that the heterotrophs disproportionally outnumbered the algae in the sample and that the random picking of clones was biased towards the dominant clone sequences of heterotrophs. This result indicated that more specific PCR primers that target and primarily amplify genomic DNA of freshwater algae must be designed and tested in future studies [43].

Many of the sequences we obtained were not identifiable as algae based on the database sequence comparison search. As previously mentioned, the number of available algal sequences in the current existing nucleotide database was one of the potential limiting factors for the full employment of this molecular approach. In addition, it is possible that there are many taxa new to science in mud samples that need to be explored. The characterization of the comprehensive diversity of algae by molecular means is possible only when enough $18 \mathrm{~S}$ rDNA sequences associated with specific algal species become available. In this regard, determining the proper culture conditions for developing algal monocultures from environmental samples will be critical to increase the algal sequences in the nucleotide database. 


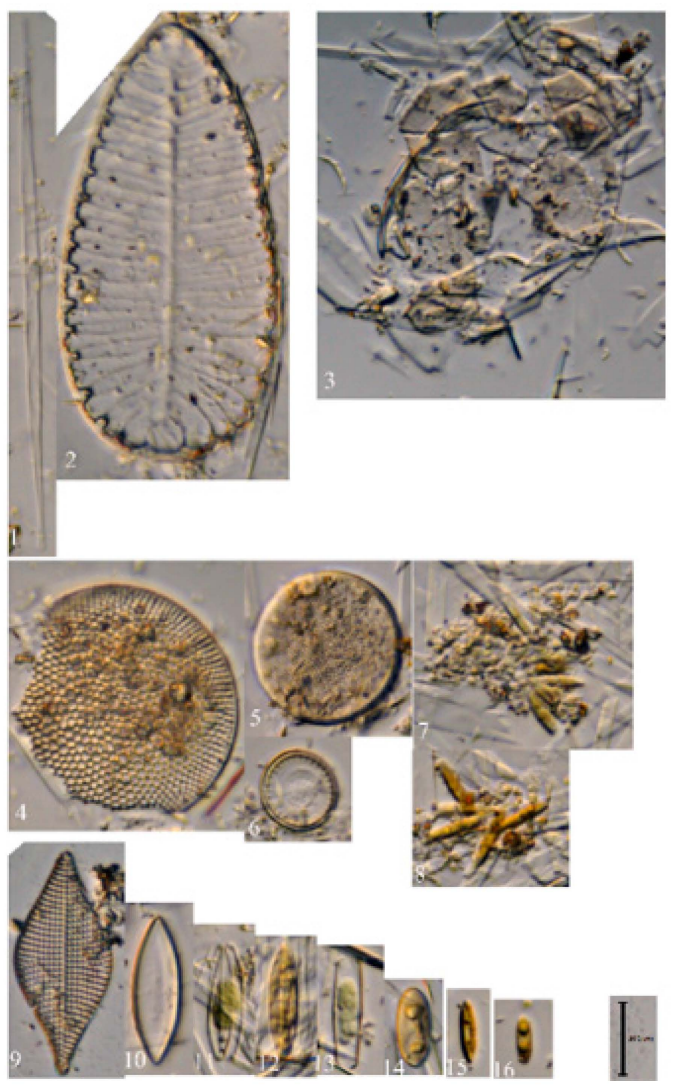

Figure 4. Diatoms subjected to "bead beating" as a part of the DNA extraction protocol. Observations of the remaining lysis buffer sample with beads after total genomic DNA extraction was completed; $(\mathbf{1 - 6 , 9 , 1 0 )}$ Diatoms from the Savannah River, GA, field samples; $(\mathbf{7 , 8 , 1 1 - 1 6 )}$ Cultures developed at the laboratory: intact cells $(\mathbf{1}, \mathbf{2 , 5 , 6})$, with chloroplasts $(\mathbf{7 , 8 , 1 1 - 1 6 )}$ and broken cells $(\mathbf{3}, \mathbf{4})$. (1) Cylindrotheca gracilis (Brébisson) Grunow; (2) Surirella splendida (Ehrenberg) Kützing; (3) Thalassiosira sp.; $(\mathbf{4}, \mathbf{5})$ Coscinodiscus sp.; (6) Puncticulata sp.; $(\mathbf{7 , 8 , 1 5 , 1 6 ) ~ N i t z s c h i a ~ s p . ; ~ ( 9 ) ~ R h a p h o n e i s ~ a m p h i c e r o s ~ E h r e n b e r g ; ~}$ (10) Tryblionella sp.; (11-14) Naviculoid pennate diatoms; Scale bar $20 \mu \mathrm{m}$.

\section{Conclusions}

As a result of this research, we identified, for the first time, all algal groups inhabiting the mudflats of the Savannah River and found that diatoms dominated the community. We obtained a comprehensive dataset of the algal diversity in the Savannah River mudflats. In addition, we documented the diatoms that survived the standard DNA extraction procedures, and these diatoms remained morphologically intact and were physiologically active in some cases. The morphological classification of algal species has been historically difficult, due to the paucity of readily observable characteristics of taxonomic value [16]. Incorporation of molecular data in community analyses remains an attractive solution of problems with morphological analyses, and we can envision great potential regardless of the scarcity of direct matches in this research.

The application of molecular techniques has begun to revolutionize algal taxonomy [44,45]. Most recently, the combination of universal primers of $16 \mathrm{~S} / 18 \mathrm{~S}$ ribosomal RNA genes using the latest next-generation sequencing technology has resulted in many new discoveries regarding algal diversity in aquatic ecosystems [46]. The phylogenetic diversity derived from molecular data was demonstrated to be the best predictor of ecosystem function in several systems, but this work has not been attempted for mudflat communities [13]. Morphological identification and next-generation sequencing are currently becoming important for ecological inferences, such as the absolute and relative abundance of species within riverine mudflat communities [47]. Morphological identification, however, will remain 
extremely relevant for the description of new-to-science taxa and for the assessment of biodiversity. Overall, the molecular approach we employed in our study has great potential to contribute to the current understanding of algal diversity in the future. In a recent study, the two methods were successfully combined-DNA from Neidium cultures was amplified using a nested PCR protocol and sequenced for rbcL and $18 \mathrm{~S}$ barcoding genes with great success and potential [45]. We also refined specific experimental parameters for future experiments. We expect that the morphological and molecular techniques will continue to evolve with new technological approaches $[46,48]$. There were reports of new diatoms' descriptions in diverse aquatic habitats with morphological descriptions of living populations [48] in which sequence data from preserved or live samples amended the taxonomy by a designated holotype $[45,49]$. Very high species richness from marine sediments was previously reported [50,51] without information on physiological state at time of collection and related to what was deposited in the sediment or actually responding to the conditions of this environment. Our methods allowed obtaining an understanding of the ecology of algae in the sediments. The majority of diatoms in the sediment were not physiologically active (i.e., we did not observe chloroplasts), but they were potentially deposited as silica cell wall particles. More culture-based sequences and molecular information in publically available databases will shorten the time needed for algal identification and community based bioassessment. We expect that the refined version of the combined methodology that we presented here will continue to be tested [52] and proven effective.

Acknowledgments: J.N.D.J. and A.G. used parts of this work in fulfillment of a partial requirement for Master's research at GCSU. The authors thank the Department of Biological and Environmental Sciences for support. GCSU 1002060 to K.M.M. funded this research.

Author Contributions: K.M.M. completed the taxonomic identification and enumeration of diatoms, analyzed data, and wrote parts of the manuscript. Y.K.E.F. analyzed molecular data and wrote parts of the manuscript. A.G. performed the genome analyses, database search, and wrote parts of the manuscript. J.N.D.J. collected samples, maintained cultures, enumerated algae, and wrote parts of the manuscript.

Conflicts of Interest: The authors declare no conflict of interest.

\section{References}

1. Pritchard, D. What is an estuary: Physical viewpoint. In Estuaries; Lauff, G., Ed.; American Association for the Advancement of Science: Washington, DC, USA, 1967.

2. NRC (National Research Council). Clean Coastal Waters: Understanding and Reducing the Effects of Nutrient Pollution; National Academy Press: Washington, DC, USA, 2000.

3. Rabalais, N.N.; Turner, R.E.; Wiseman, W.J.; Boesch, D.F. A brief summary of hypoxia on the northern Gulf of Mexico continental shelf: 1985-1988. In Geological Society; Tyson, R.V., Pearson, T.H., Eds.; The Geological Society: London, UK, 1991.

4. Vos, P.C.; de Wolf, H. Methodological aspects of palaeoecological diatom research in coastal areas of the Netherlands. Geol. Mijnb. 1988, 67, 31-40.

5. Morrisey, D.J. Differences in effects of grazing by deposit-feeders Hydrobia ulvae (Pennant) (Gastropoda: Prosobranchia) and Corophium arenarium Crawford (Amphipoda) on sediment microalgal populations. II. Quantitative effects. J. Exp. Mar. Biol. Ecol. 1988, 118, 43-53. [CrossRef]

6. Underwood, G.J.C.; Paterson, D.M. Recovery of intertidal benthic diatoms after biocide treatment and associated sediment dynamics. J. Mar. Biol. Assoc. UK 1993, 73, 25-45. [CrossRef]

7. Underwood, G.J.C.; Paterson, D.M. Seasonal changes in diatom biomass, sediment stability and biogenic stabilization in the Severn Estuary. J. Exp. Mar. Biol. Ecol. 1993, 73, 871-887. [CrossRef]

8. Admiraal, W.; Peletier, H.; Brouwer, T. The seasonal succession patterns of diatom species on an intertidal mudflat: An experimental analysis. Oikos 1984, 42, 30-40. [CrossRef]

9. Underwood, G.J.C. Seasonal and Spatial variation in epipelic diatom assemblages in the Severn estuary. Diatom Res. 1994, 9, 451-472. [CrossRef]

10. Graham, J.E.; Graham, L.E.; Wilcox, L.W. Algae, 2nd ed.; Benjamin Cummings: San Francisco, CA, USA, 2009; p. 616.

11. Andersen, R.A. Diversity of eukaryotic algae. Biodivers. Conserv. 1992, 1, 267-292. [CrossRef] 
12. Corinaldesi, C.; Beolchini, F.; Dell'Anno, A. Damage and degradation rates of extracellular DNA in marine sediments: Implications for the preservation of gene sequences. Mol. Ecol. 2008, 17, 3939-3951. [CrossRef] [PubMed]

13. Keck, F.; Rimet, F.; Franc, A.; Bouchez, A. Phylogenetic signal in diatom ecology: Perspectives for aquatic ecosystems biomonitoring. Ecol. Appl. 2015. [CrossRef]

14. Chessman, B.C.; Bate, N.; Gell, P.A.; Newall, P. A diatom species index for bioassessment of Australian rivers. Mar. Freshw. Res. 2007, 58, 542-557. [CrossRef]

15. Stevenson, R.J.; Pan, Y.; Manoylov, K.M.; Parker, C.A.; Larsen, D.P.; Herlihy, A.T. Development of diatom indicators of ecological conditions for streams of the western US. J. N. Am. Benthol. Soc. 2008, 27, 1000-1016. [CrossRef]

16. Manoylov, K.M.; Dominy, J.N., Jr. Changes in epipelic diatom diversity from the Savannah River Estuary. J. Environ. Prot. 2013, 4, 172-179. [CrossRef]

17. Manoylov, K.M. Taxonomic identifications of algae (morphological and molecular), species concepts, methodologies, and their implications for ecological bioassessment. J. Phycol. 2014, 50, 409-424. [CrossRef]

18. Savin, M.C.; Martin, J.L.; LeGresley, M.; Giewat, M.; Rooney-Varga, J. Plankton diversity in the Bay of Fundy as measured by morphological and molecular methods. Microb. Ecol. 2004, 48, 51-65. [CrossRef] [PubMed]

19. Medlin, L.K. Application of molecular techniques for genetic differentiation of microalgae. In Out of the Past. Collected Reviews to Celebrate the Jubilee of the British Phycological Society; Northon, T.A., Ed.; Dataplus Print \& Design (Dunmurry): Belfast, UK, 2003; pp. 31-48.

20. Moon-van der Staay, S.Y.; van der Staay, G.W.M.; Guillou, L.; Vaulot, D.; Claustre, H.; Medlin, L.K. Abundance and diversity of prymnesiophytes in the picoplankton community from the equatorial Pacific Ocean inferred from 18S rDNA sequences. Limnol. Oceanogr. 2000, 45, 98-109. [CrossRef]

21. Pace, N.R.; Stahl, D.A.; Lane, D.J.; Olsen, G.J. The analysis of natural microbial populations by ribosomal RNA sequences. Adv. Microb. Ecol. 1986, 9, 1-55.

22. López-García, P.; Rodríguez-Valera, F.; Pedrós-Alió, C.; Moreira, D. Unexpected diversity of small eukaryotes in deep-sea Antarctic plankton. Nature 2001, 409, 603-607. [CrossRef] [PubMed]

23. Moon-van der Staay, S.Y.; de Wachter, R.; Vaulot, D. Oceanic $18 S$ rDNA sequences from picoplankton reveal unsuspected eukaryotic diversity. Nature 2001, 409, 607-610. [CrossRef] [PubMed]

24. Viprey, M.; Guillou, L.; Ferreol, M.; Vaulot, D. Wide genetic diversity of picoplanktonic green algae (Chloroplastida) in the Mediterranean Sea uncovered by a phylum-biased PCR approach. Environ. Microbiol. 2008, 10, 1804-1822. [CrossRef] [PubMed]

25. American Public Health Association (APHA). Standard Methods for Examination of Water and Wastewater; American Public Health Association: Washington, DC, USA, 1998.

26. Dominy, J.D., Jr. Algal Population Dynamics within the Savannah River Estuary. Master's Thesis, Georgia College \& State University, Milledgeville, GA, USA, 2012.

27. Palmer, C.M.; Maloney, T.E. A New Counting Slide for Nanoplankton; American Society of Limnology and Oceanography Special Publication: Waco, TX, USA, 1954; p. 6.

28. Krammer, K.; Lange-Bertalot, H. Bacillariophyceae. 1. Teil: Naviculaceae. In Süsswasserflora von Mitteleuropa; Ettl, H., Gerloff, J., Heynig, H., Mollenhauer, D., Eds.; Gustav Fisher Verlag: Jena, Germany, 1986; pp. 1-876.

29. Krammer, K.; Lange-Bertalot, H. Bacillariophyceae. 2. Teil: Bacillariaceae, Epithemiaceae, Surirellaceae. In Süsswasserflora von Mitteleuropa; Ettl, H., Gerloff, J., Heynig, H., Mollenhauer, D., Eds.; Gustav Fisher Verlag: Jena, Germany, 1988; pp. 1-596.

30. Krammer, K.; Lange-Bertalot, H. Bacillariophyceae. 3. Teil: Centrales, Fragilariaceae, Eunotiaceae. In Süsswasserflora von Mitteleuropa; Ettl, H., Gerloff, J., Heynig, H., Mollenhauer, D., Eds.; Gustav Fisher Verlag: Jena, Germany, 1991; pp. 1-576.

31. Krammer, K.; Lange-Bertalot, H. Bacillariophyceae. 4. Teil: Achnanthaceae. Kritische Ergänzungen zu Navicula (Lineolatae) und Gomphonema. In Süsswasserflora von Mitteleuropa; Ettl, H., Gerloff, J., Heynig, H., Mollenhauer, D., Eds.; Gustav Fisher Verlag: Jena, Germany, 1991; pp. 1-437.

32. Witkowski, A.; Lange-Bertalot, H.; Metzeltin, D. Diatom Flora of Marine Coasts I. In Iconographia Diatomologica Annotated Diatom Micrograph; Lange-Bertalot, H., Ed.; A.R.G. Gantner Verlag K. G.: Ruggell, Germany, 2008.

33. Hofmann, G.; Werum, M.; Lange-Bertalot, H. Diatomeen im Süßwasser Benthos von Mitteleuropa. Bestimmungsflora Kieselalgen für die ökologische Praxis. Über 700 der häufigsten Arten und ihre Ökologie; Koeltz Scientific Books: Oberreifenberg, Germany, 2013. 
34. Manoylov, K.M.; Marsh, T.; Stevenson, R.J. Testing molecular tools for assessment of taxonomic composition of a benthic algal community. Nova Hedwig. Beih. 2009, 135, 121-136.

35. Kearse, M.; Moir, R.; Wilson, A.; Stones-Havas, S.; Cheung, M.; Sturrock, S.; Buxton, S.; Cooper, A.; Markowitz, S.; Duran, C.; et al. Geneious Basic: An integrated and extendable desktop software platform for the organization and analysis of sequence data. Bioinformatics 2012, 28, 1647-1649. [CrossRef] [PubMed]

36. Ashelford, K.E.; Chuzhanova, N.A.; Fry, J.C.; Jones, A.J.; Weightman, A.J. New screening software shows that most recent large 16S rRNA gene clone libraries contain chimeras. Appl. Environ. Microbiol. 2006, 72, 5734-5741. [CrossRef] [PubMed]

37. Ashelford, K.E.; Chuzhanova, N.A.; Fry, J.C.; Jones, A.J.; Weightman, A.J. At least 1 in 20 16S rRNA sequence records currently held in public repositories is estimated to contain substantial anomalies. Appl. Environ. Microbiol. 2005, 71, 7724-7736. [CrossRef] [PubMed]

38. Larkin, M.A.; Blackshields, G.; Brown, N.P.; Chenna, R.; McGettigan, P.A.; McWilliam, H.; Higgins, D.G. Clustal W and Clustal X version 2.0. Bioinformatics 2007, 23, 2947-2948. [CrossRef] [PubMed]

39. Goujon, M.; McWilliam, H.; Li, W.; Valentin, F.; Squizzato, S.; Paern, J.; Lopez, R. A new bioinformatics analysis tools framework at EMBL-EBI. Nucleic Acids Res. 2010, 38, 695-699. [CrossRef] [PubMed]

40. Pruesse, E.; Quast, C.; Knittel, K.; Fuchs, B.M.; Ludwig, W.; Peplies, J.; Glockner, F.O. SILVA: A comprehensive online resource for quality checked and aligned ribosomal RNA sequence data compatible with ARB. Nucleic Acids Res. 2007, 35, 7188-7196. [CrossRef] [PubMed]

41. Riley-Buckley, M.S. Microbial Communities in Pristine and Tetrachloroethylene-Contaminated Aquifer Sediment. Ph.D. Thesis, Michigan State University, East Lansing, MI, USA, 2001.

42. Nguyen, T.N.; Berzano, M.; Gualerzi, C.O.; Spurio, R. Development of molecular tools for the detection of freshwater diatoms. J. Microbiol. Method 2011, 84, 33-40. [CrossRef] [PubMed]

43. Geletu, A. Assessment of Molecular Approaches in Studying Algal Diversity. Master's Thesis, Georgia College \& State University, Milledgeville, GA, USA, 2012.

44. Kermarrec, L.; Franc, A.; Rimet, F.; Chaumeil, P.; Frigerio, J.M.; Humbert, J.F.; Bouchez, A. A next-generation sequencing approach to river biomonitoring using benthic diatoms. Freshw. Sci. 2014, 33, 349-364. [CrossRef]

45. Lefebvre, K.E.; Hamilton, P.E. Morphology and molecular studies on large Neidium species (Bacillariophyta) of North America, including an examination of Ehrenberg's types. Phytotaxa 2015, 220, 201-223. [CrossRef]

46. Quaiser, A.; Zivanovic, Y.; Moreira, D.; Lopez-Garcia, P. Comparative metagenomics of bathypelagic plankton and bottom sediment from the Sea of Marmara. ISME J. 2011, 5, 285-304. [CrossRef] [PubMed]

47. Flynn, D.F.B.; Mirotchnick, N.; Jain, M.; Palmer, M.I.; Naeem, S. Functional and phylogenetic diversity as predictors of biodiversity-ecosystem-function relationships. Ecology 2011, 92, 1573-1581. [CrossRef] [PubMed]

48. Zimmermann, J.; Glöckner, G.; Jahn, R.; Enke, N.; Gemeinholzer, B. Metabarcoding vs. morphological identification to assess diatom diversity in environmental studies. Mol. Ecol. Res. 2015, 15, 526-542. [CrossRef] [PubMed]

49. Li, C.L.; Ashworth, M.P.; Witkowski, A.; Dabek, P.; Medlin, L.K.; Kooistra, W.H.C.F.; Sato, S.; Zgłobicka, I.; Kurzydłowski, K.J.; Theriot, E.C.; et al. New insights into Plagiogrammaceae (Bacillariophyta) based on multigene phylogenies and morphological characteristics with the description of a new genus and three new species. PLoS ONE 2015, 10. [CrossRef] [PubMed]

50. Capo, E.; Debroas, D.; Domaizon, I. Is planktonic diversity well recorded in sedimentary DNA? Toward the Reconstruction of Past Protistan Diversity. Microbiol. Ecol. 2015, 70, 865-875. [CrossRef] [PubMed]

51. Hustedt, F. Marine Littoral Diatoms of Beaufort, North Carolina; Duke University Press: Durham, NC, USA, 1955; Volume 6, p. 167.

52. Kermarrec, L.; Franc, A.; Rimet, F.; Chaumeil, P.; Humbert, J.F.; Bouchez, A. Next-generation sequencing to inventory taxonomic diversity in eukaryotic communities: A test for freshwater diatoms. Mol. Ecol. Res. 2013, 13, 607-619. [CrossRef] [PubMed]

(C) 2016 by the authors; licensee MDPI, Basel, Switzerland. This article is an open access article distributed under the terms and conditions of the Creative Commons by Attribution (CC-BY) license (http://creativecommons.org/licenses/by/4.0/). 